UDC 577.25

doi: https://doi.org/10.15407/ubj88.05.082

\title{
EFFECT OF NITRIC OXIDE DONOR SNAP ON GABA RELEASE FROM RAT BRAIN NERVE TERMINALS
}

\author{
A. S. TARASENKO \\ Palladin Institute of Biochemistry, National Academy of Sciences of Ukraine, Kyiv; \\ e-mail:tas@biochem.kiev.ua
}

\begin{abstract}
In this work we investigated the effect of nanomolar concentrations of nitric oxide on the release of gamma-aminobutyric acid (GABA) from rat brain nerve terminals using a radioisotope method with [ $\left.{ }^{3} \mathrm{H}\right] \mathrm{GABA}$ and a spectrofluorimetric method with $\mathrm{Ca}^{2+}$-sensitive probe Fluo-4 AM. It was shown that in the presence of dithiothreitol (DTT), nitric oxide donor SNAP at concentration, in which it produces NO in the nanomolar range, caused $\mathrm{Ca}^{2+}$-independent $\left.{ }^{3} \mathrm{H}\right] \mathrm{GABA}$ release from nerve terminals. The applications of 4-aminopyridine (4-AP) and nipecotic acid (NA), as the inducers of GABA release from vesicular and cytoplasmic pools, showed that the maximum of $S N A P /+D T T$-induced $\left.{ }^{3} H\right] G A B A$ release was registered at $10^{\text {th }}$ min of incubation and coincided in time with significant increase (almost double) in NA-induced $\left[{ }^{3} \mathrm{H}\right] \mathrm{GABA}$ release. At this time point, 4-AP-induced release of [ $\left.{ }^{3} H\right] G A B A$ was drastically reduced. At the $15^{\text {th }}$ min of incubation of nerve terminals with $S N A P /+D T T$, the opposite picture was observed: the decrease in NA- and increase in 4-AP-induced $\left[{ }^{3} H\right] G A B A$ release. Thus, nitric oxide in the form of S-nitrosothiols at nanomolar concentrations causes $\mathrm{Ca}^{2+}$-independent GABA leakage from synaptic vesicles into cytosol with subsequent release from nerve terminals. The reuptake of the neurotransmitter and its re-accumulation in synaptic vesicles occur later.
\end{abstract}

Key words: nitric oxide, GABA release, vesicular and cytoplasmic pool.

$\mathrm{N}$ itric oxide (NO) is a unique signalling molecule that is involved in key body's vital processes. In the central nervous system, nitric oxide modulates the efficiency of synaptic transmission and affects the formation of prolonged connections between neurons that underlies the cognitive brain functions: memory and learning. The physiological function of NO in brain is closely related to its ability to modulate the release of neurotransmitters. Freely diffusing into the presynaptic terminal, nitric oxide affects the release of almost all known classes of neurotransmitters, exhibiting both stimulating [1] and inhibitory [2] effects on neurotransmission. Some authors believe that NO acting on the presynapse exhibits multidirectional effect, namely reducing the stimulated release of neurotransmitters and, at the same time, increasing the spontaneous release of neurotransmitters [3].

GABA is one of the key inhibitory neurotransmitters, which controls neural tissue excitability and affects high integrative brain functions. In vivo GABAergic neurotransmission can be modulated by nitric oxide released from NO-containing drugs, glial cells or postsynaptic nerve terminals due to the activation of, for example, postsynaptic NMDAtype glutamate receptors [4]. Concerning the latter,
$\mathrm{NO}$ acts as a retrograde messenger that diffuses into presynaptic terminals and modulates neurotransmitter release. It was shown that the release of GABA from nerve terminals can occur via the classical pathway, exocytosis [5], as well as via plasma membrane GABA transporter reversal [6]. There is also an opinion that NO, affecting the GABAergic terminals, engages both pathways: inhibiting exocytosis and stimulating the transporter-mediated GABA release [7].

Ambiguity and sometimes contradictory data on the effect of NO on the release of neurotransmitters can be a result from different redox-status of $\mathrm{NO}$ molecule $\left(\mathrm{NO}^{*}, \mathrm{NO}^{-}\right.$or $\left.\mathrm{NO}^{+}\right)$of nitric oxide donors generally used in experiments [8]. Therefore, the effects of $\mathrm{NO}$ can be mediated by activation of different intracellular signaling pathways, in particular, S-nitrosylation of neuronal protein thiol groups [9] or activation of soluble guanylate cyclase [10]. Concentration of nitric oxide also plays an important role, since at its high concentration mechanisms of oxidative stress, mitochondrial dysfunction and excitotoxicity are activated [11].

Given the aforementioned, the aim of this work was to study the effect of low (nanomolar) concentrations of nitric oxide on GABA release from 
isolated rat brain nerve terminals (synaptosomes). As the NO donor, we used SNAP (S-nitroso-Nacetylpenicillamine), which belongs to the class of natural metabolite of nitric oxide. Biological effect of S-nitrosothiols is mediated via direct effect of NO molecules spontaneously released due to homolytic $\mathrm{S}-\mathrm{N}$ bond cleavage, as well as via a transnitrosation reaction - nitrosonium ion $\left(\mathrm{NO}^{+}\right)$transfer to thiolcontaining compounds (peptides, enzymes, etc.). In the range of SNAP concentration from 0.1 to $1 \mathrm{mM}$, the concentration of free $\mathrm{NO}$ is found to be in the nanomolar range from 20 to $100 \mathrm{nM}$ [12].

\section{Materials and Methods}

All animal experiments were performed in accordance with the rules and regulations of the European Convention for the Protection of Vertebrate Animals used for Experimental and Other Scientific Purposes (Strasbourg, 1986). Male white Wistar rats weighing 150-200 g were used in the study. Animals were maintained in standard cages under natural light conditions on standard rodent diet with free access to food and water. In the experimental day, the animals were decapitated under chloroform anesthesia, after that, hippocampus and cerebral cortex were immediately isolated and homogenized in cool isolation medium consisting of: $0.32 \mathrm{M}$ sucrose, $0.2 \mathrm{mM}$ EGTA, 5 mM HEPES, pH 7.4 using glass Poter homogenizer (clearance $0.2 \mathrm{~mm}$ ). Purified fraction of isolated nerve terminals (synaptosomes) were prepared using Cotman method [13], by suspending precipitate after the last centrifugation in standard cool oxygenated incubation medium composed of (mM): $\mathrm{NaCl}-126, \mathrm{KCl}-5, \mathrm{CaCl}_{2}-1, \mathrm{MgCl}_{2}-1.4$, $\mathrm{NaH}_{2} \mathrm{PO}_{4}-1$, HEPES - 20 (pH 7.4), d-glucose 10. All the procedures were carried out at $0-4{ }^{\circ} \mathrm{C}$. Protein concentration was determined by the Lowry method in Larson modifications [14].

GABA release from synaptosomes was determined using radioisotope method with tritiated GABA $\left(5 \times 10^{-7} \mathrm{M}\right)$. To prevent degradation of neurotransmitter, the experiments were carried out in the presence of aminooxyacetic acid $(100 \mu \mathrm{M})$, GABA-transaminase inhibitor. The $\left[{ }^{3} \mathrm{H}\right] \mathrm{GABA}$ release from synaptosomes without adding stimulating agents was taken as the basal release. SNAP-induced release was calculated as the difference between the $\left[{ }^{3} \mathrm{H}\right] \mathrm{GABA}$ release in the presence of SNAP and the basal release. GABA release from vesicular pool was induced by addition of 4-aminopyridine (4-AP) and determined as difference between 4-AP-induced $\left[{ }^{3} \mathrm{H}\right] \mathrm{GABA}$ release from control synaptosomes and synaptosomes preincubated with SNAP. GABA release from cytoplasm pool was induced by nipecotic acid (NA). 4-AP/NA was added to synaptosomes at different time points their incubation with SNAP, and after $5 \mathrm{~min}$ the aliquots were centrifuged at $12000 \mathrm{rpm}$ for $15 \mathrm{sec}$ and the supernatants were collected. The content of $\left[{ }^{3} \mathrm{H}\right] \mathrm{GABA}$ in the supernatant was measured using a liquid scintillation counter Tracor Analytic Delta 300 with ACS scintillation liquid, and was expressed as a percentage of total $\left[{ }^{3} \mathrm{H}\right] \mathrm{GABA}$ in synaptosomes. Results are presented as mean \pm SEM.

Relative changes of ionized calcium levels within synaptosomes were assessed using fluorescent $\mathrm{Ca}^{2+}$-sensitive probe Fluo-4 AM according to standard procedure. Kinetic measurements were performed using a spectrofluorometer QuantaMaster 40 (PTI, FelixGX-4.1.0) at $\lambda_{\text {ex }}=496 \mathrm{~nm}$ and $\lambda_{\mathrm{em}}=518 \mathrm{~nm}$. Criteria for synaptosome functionality were their responses to application of calcium ionophore A 23187 (final concentration $5 \mu \mathrm{M}$ ) and $\mathrm{KCl}$ (final concentration $30 \mathrm{mM}$ ). Statistical data processing and graphing were performed using Microsoft Origin Pro 9.0 software. Statistical significance was calculated using ANOVA with Bonferroni correction for multiple comparisons. The differences were considered significant at $P<0.05 / n$ (where $n$ is the number of determined parameters).

The following reagents were used in the experiments: $\left[{ }^{3} \mathrm{H}\right] \mathrm{GABA}(94 \mathrm{Ci} / \mathrm{mol})$, ASC scintillation liquid (Amersham, UK), 4-aminopyridine (RBI, USA), SNAP (S-nitroso-N-acetylpenicillamine), dithiothreitol, nipecotic acid, Ficoll-400, aminooxyacetate, d-glucose, HEPES (Sigma, USA), Fluo-4 AM (Invitrogen, USA) and other reagents (Reachim, Ukraine).

\section{Results and Discussion}

The first step in our study of the effect of nitric oxide on GABAergic nerve terminals was time measurements of the amount of radiolabeled GABA released from synaptosomes during their incubation with SNAP. As it can be seen (Fig. 1, A), 10 min after addition of SNAP $(100 \mu \mathrm{M})$ to $\left[{ }^{3} \mathrm{H}\right] \mathrm{GABA}$-loaded synaptosome, the amount of the extrasynaptosomal neurotransmitter (minus basal release) was insignificant $(1.1 \pm 0.52 \%)$. This indicates that SNAP itself, which at this concentration spontaneously releases $\mathrm{NO}$ in a concentration of several nM [15], had little effect on the inhibitory neurotransmission. Howe- 
ver, the picture drastically changed in the presence of $1 \mathrm{mM}$ DTT in the incubation medium. According to the literature and our data, the biological effect of S-nitrosothiols, including SNAP, is significantly enhanced in the presence of low molecular mass thiols that is associated with the formation of the highly reactive intermediates and additional NO release due to fast SNAP cleavage $[15,16]$. As it is seen in Fig. 1, the amount of $\left[{ }^{3} \mathrm{H}\right] \mathrm{GABA}$ released from the synaptosomes at the $5^{\text {th }}$ min of the SNAP action was $5.19 \pm 0.52 \%$, and at the $10^{\text {th }}$ min of incubation, this value increased to $8.05 \pm 0.24 \%$. However, further elevation in the extrasynaptosomal $\left[{ }^{3} \mathrm{H}\right] \mathrm{GABA}$ level was not observed, and, on the contrary, at the $15^{\text {th }}$ min of incubation the level of $\left[{ }^{3} \mathrm{H}\right]$ GABA sharply dropped to almost $1.19 \pm 0.78 \%$ that is likely to reflect the dynamic $\left[{ }^{3} \mathrm{H}\right] \mathrm{GABA}$ uptake into synaptosomes. The assumption about the mechanisms for this SNAP/+DTT effect will be made later. It should be only noted that DTT itself stabilized presynaptic terminals reducing the basal release of radiolabeled neurotransmitter (Fig. 1, the second column).

SNAP/+DTT-induced release of $\left[{ }^{3} \mathrm{H}\right] \mathrm{GABA}$ was found to be insensitive to the absence of calcium ions in the incubation medium (Fig. 1, B), indicating that the release does not occur due to classical synchronous exocytosis. $\mathrm{Ca}^{2+}$-independent neurotransmitter release under the action of NO has been described previously [10, 17], and can be a consequence of the involvement of intracellular calcium stores and activation of spontaneous GABA release. The spontaneous process, unlike synchronous, is believed to occur asynchronously and triggered by calcium ions, which are released from intracellular stores into cytosol [18]. Thus, the next step of the study was to clarify the involvement of intracellular calcium stores in SNAP/+DTT-induced $\left[{ }^{3} \mathrm{H}\right] \mathrm{GABA}$ release.

Relative changes in the concentration of ionized calcium inside synaptosomes $\left[\mathrm{Ca}^{2+}\right]_{\text {in }}$ were assessed using a fluorescent probe Fluo-4 AM, which after cleavage by intracellular esterases and binding with calcium ions emits in the green spectral band. As it is shown in Fig. 2, $A$, addition of SNAP $(100 \mu \mathrm{M})$ to a suspension of synaptosomes preincubated with DTT $(1 \mathrm{mM})$ in $\mathrm{Ca}^{2+}$-free medium $(+0.1 \mathrm{mM}$ EGTA) was not accompanied by a change in Fluo-4 fluorescence that indicated a lack of increase in $\left[\mathrm{Ca}^{2+}\right]_{\text {in }}$ upon action of nanomolar concentrations of SNAP. However, the addition to synaptosomes of $\mathrm{Ca}^{2+}$-ionophore A-23187 $(5 \mu \mathrm{M})$ led to a fluores-
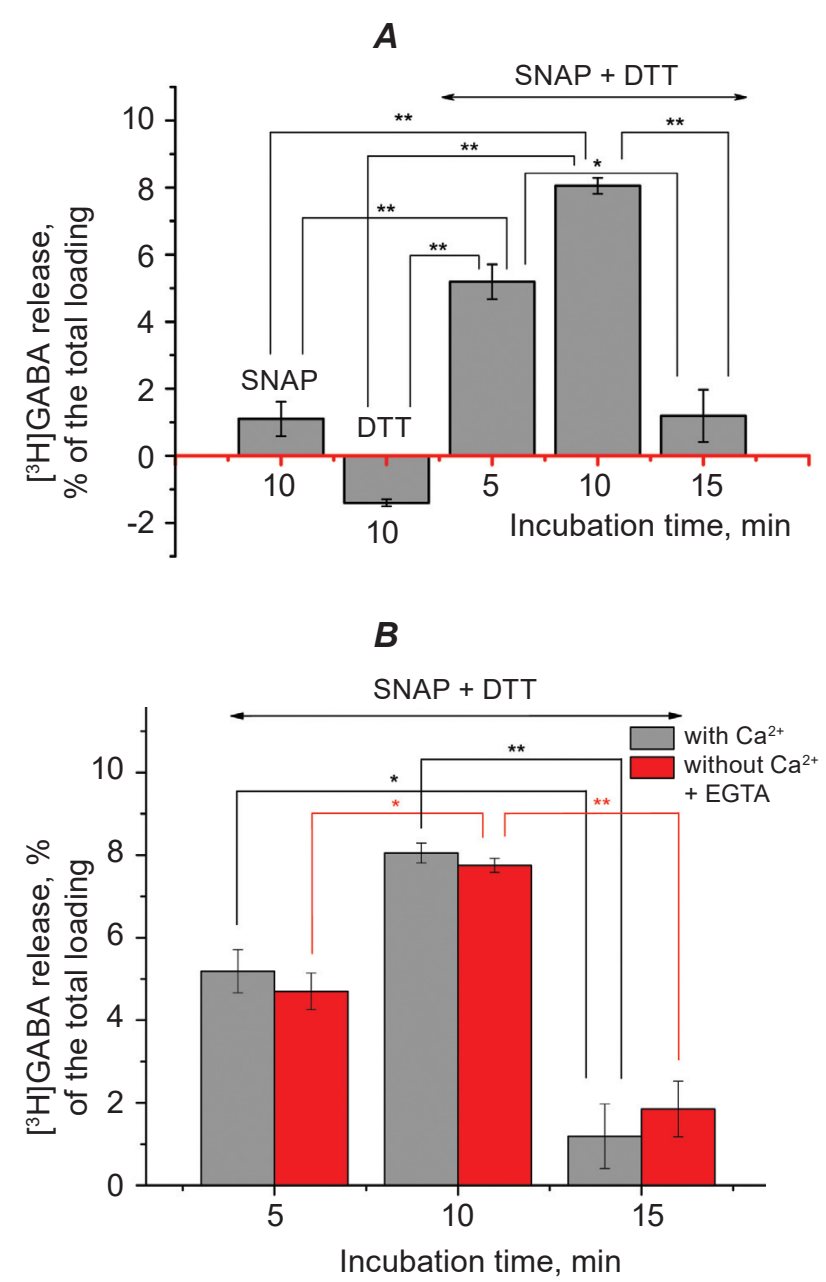

Fig. 1. [ $\left.{ }^{3} H\right] G A B A$ release from synaptosomes under the action of SNAP $(100 \mu M)$ and/or DTT $(1 \mathrm{mM})$ in the $\mathrm{Ca}^{2+}$-containing (A) and $\mathrm{Ca}^{2+}$-free/ $+0.1 \mathrm{mM}$ EGTA (B) incubation medium; mean $\pm S E M, n=4$, $* P<0.05 ; * * P<0.01$

cence burst due to an increase in the concentration of calcium released from intracellular store - mitochondria and endoplasmic reticulum. Other criteria of synaptosome functionality was the application of $\mathrm{KCl}(30 \mathrm{mM})$, which, as expected, did not affect the fluorescence intensity of Fluo-4 in $\mathrm{Ca}^{2+}$-free medium (Fig. 2, A), however caused a sharp increase in fluorescence in the presence of $1 \mathrm{mM} \mathrm{Ca}^{2+}$ (Fig. 2, $B)$. The latter is related to the influx of extrasynaptosomal calcium into synaptosomes through potential-regulated channels due to $\mathrm{KCl}$-induced plasma membrane depolarization. It should be noted that the addition of $100 \mu \mathrm{M} \mathrm{SNAP/+DTT} \mathrm{to} \mathrm{synaptosomes} \mathrm{in}$ the $\mathrm{Ca}^{2+}$-containing medium also did not affect the calcium concentration in synaptosomes (Fig. 2, B), and this allows us to hypothesize that SNAP/+DTT- 

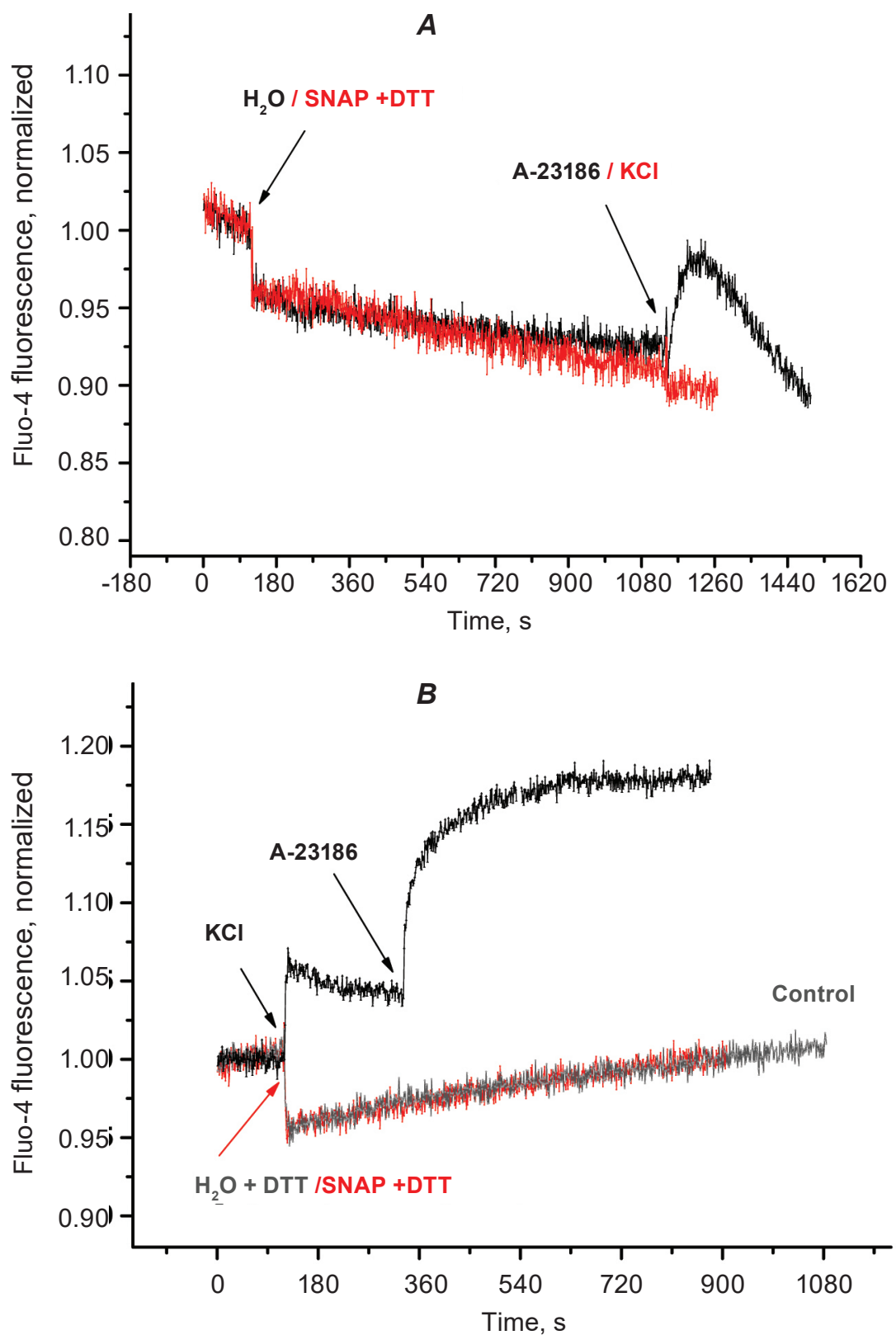

Fig. 2. Relative changes in ionized calcium level inside synaptosomes under the action of SNAP/+DTT $(100 \mu \mathrm{M} / 1 \mathrm{mM})$ in $\mathrm{Ca}^{2+}$-free /+0.1 mM EGTA (A) and $\mathrm{Ca}^{2+}$-containing (B) incubation medium. Responses to the addition of $\mathrm{KCl}(30 \mathrm{mM})$ and $\mathrm{A} 23187(5 \mu \mathrm{M})$ served as the criteria of synaptosome functionality. The typical curves are demonstrated

induced $\left[{ }^{3} \mathrm{H}\right] \mathrm{GABA}$ release does not occur by exocytosis (spontaneous and/or synchronous), but rather by engagement of other mechanisms as, fot instance, transporter-mediated.

To check this assumption, we carried out a series of experiments aimed to find out from which pools, vesicular and/or cytoplasmic, GABA is released under the action of SNAP. To this, we used potassium channel blocker 4-AP, which induces
$\mathrm{Ca}^{2+}$-dependent GABA release predominantly from vesicular pool [19], and NA, which, having the higher affinity to GABA transporters than GABA, is captured by transporters and transferred into cells in exchange for "cytoplasmic" GABA [20]. As it is seen in Fig. 3 (red columns), the addition of 4-AP $(2 \mathrm{mM})$ to synaptosomes at the $5^{\text {th }}$ and $10^{\text {th }} \mathrm{min}$ of their incubation with SNAP/+DTT $(100 \mu \mathrm{M} / 1 \mathrm{mM})$ was accompanied by a gradual decrease in the 4-AP- 


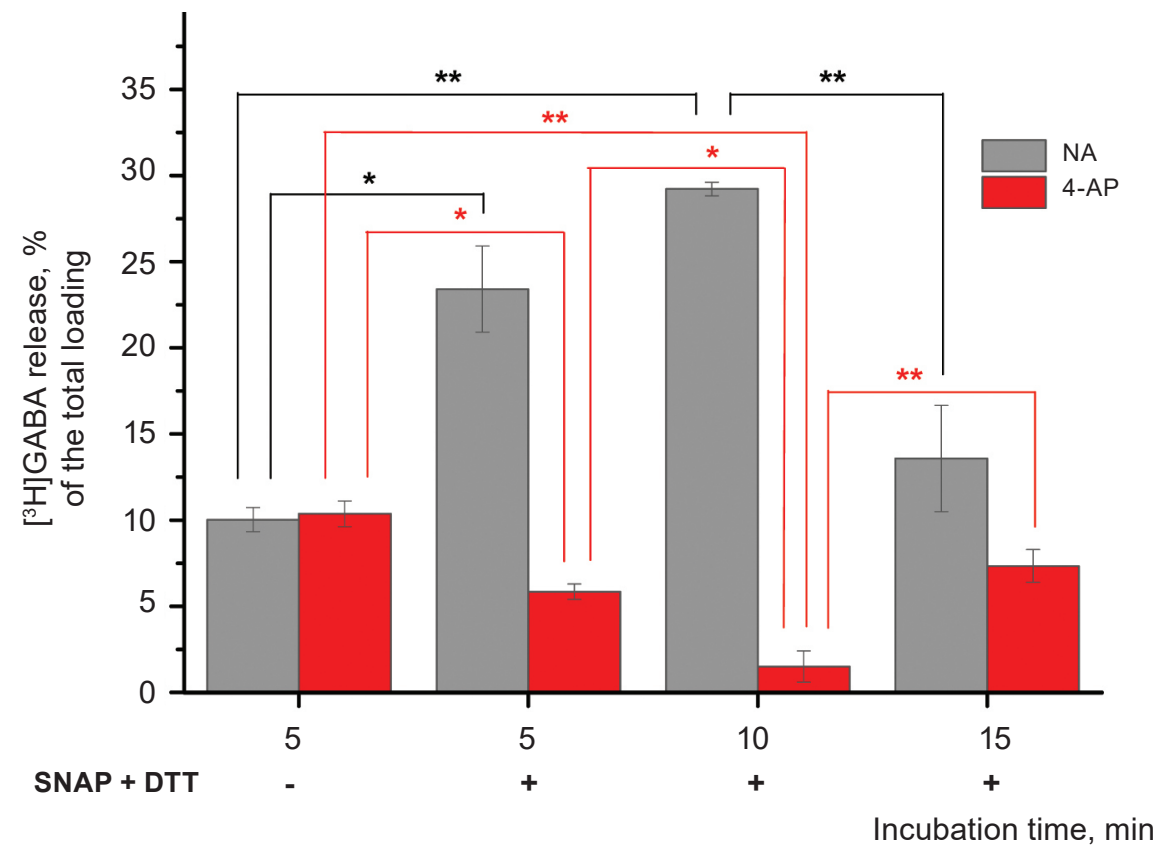

Fig. 3. NA- and 4-AP-induced [ $\left.{ }^{3} H\right] G A B A$ release from synaptosomes preincubated with $S N A P /+D T T$ for various periods of time; mean $\pm S E M, n=3, * P<0.05 ; * * P<0.01$

induced $\left[{ }^{3} \mathrm{H}\right]$ GABA release from vesicular pool, indicating its considerable depletion. However, at the $15^{\text {th }}$ min of incubation, the vesicular GABA pool was significantly restored, as evidenced by further increase in 4-AP-induced $\left[{ }^{3} \mathrm{H}\right] \mathrm{GABA}$ release (compared to the $10^{\text {th }}$ min of incubation).

Thus, the question arises: what happens to vesicular GABA pool at the $5^{\text {th }}$ and $10^{\text {th }}$ min of synaptosome incubation with SNAP/+DTT? We suggest that GABA is likely to leak from vesicles into cytoplasm and then releases out of synaptosomes. This assumption is supported by our data obtained in the experiments with nipecotic acid $(100 \mu \mathrm{M})$. We observed a gradual increase in NA-induced GABA release from cytoplasmic pool at the $5^{\text {th }}$ and $10^{\text {th }}$ min of SNAP/+DTT action (Fig. 3, grey columns). Analysis of NA- and 4-AP-induced $\left[{ }^{3} \mathrm{H}\right] \mathrm{GABA}$ release from synaptosomes clearly demonstrated that these processes are opposite-directed, that is, a decrease in vesicular GABA content was accompanied by an increase in the $\left[{ }^{3} \mathrm{H}\right] \mathrm{GABA}$ level in cytoplasm. And conversely, a decrease in cytoplasmic $\left[{ }^{3} \mathrm{H}\right] \mathrm{GABA}$ concentration at the $15^{\text {th }}$ min of incubation was correlated with the accumulation of GABA inside synaptic vesicles and, as a consequence, with an increase in the amount of $\left[{ }^{3} \mathrm{H}\right] \mathrm{GABA}$ additionally released from vesicles under the action of 4-AP. Thus, these results allow us to assume that SNAP/+DTT causes GABA release from vesicles into cytosol followed by its release out of synaptosomes, presumably, via reverse operation of GABA transporter.

NO-induced GABA release owing to the reversal of its transporters was previously demonstrated by G. Lonart and K. M. Johnson, who had found that hydroxylamine and S-nitroso-L-cysteine caused the release of dopamine and norepinephrine from striatal and hippocampal slices via pathway that was blocked by the inhibitors of their reverse uptake [21]. It should be noted that if the transporter-mediated neurotransmitter release was previously considered as a pathological process, which occurred, for example, upon ischemic or traumatic brain injury [22], but now there are experimental evidences of the involvement of transporters in the neurotransmitter release under physiological conditions. Thus, Falkenburger et al [23] showed that electrical stimulation of the brain subthalamic nuclei led to the transportermediated release of dopamine from dopamineergic dendrites in the substantia nigra, providing communication between neurons. Non-vesicular, transporter-induced GABA release, according to other authors [24], contributes to maintaining of the extracellular GABA concentration at the level sufficient to activate the high affinity GABA receptors and thus, participates in the formation of tonic inhibition. 
GABA transporters can operate in the reverse direction due to the disturbance of their dynamic equilibrium. One of the reasons for this is the change in the intracellular neurotransmitter concentration. It was shown that anticonvulsants such as gabapentin and vigabatrin, which irreversibly block GABA transaminase, caused an increase in the cytosolic concentration of GABA and, consequently, its release from the nerve terminals owing to reverse operation of transporters [25]. In our work we also assumed that SNAP/+DTT-induced $\left[{ }^{3} \mathrm{H}\right] \mathrm{GABA}$ release might be transporter-mediated, however an increase in the cytoplasmic concentration of $\left[{ }^{3} \mathrm{H}\right] \mathrm{GABA}$ is probably caused by another reason.

It is known that the accumulation of neurotransmitters in the synaptic vesicles is coupled with proton transfer into the vesicles, so the increase in cytoplasmic GABA concentration might be due to disruption in the function of a vesicular $\mathrm{H}^{+}$-ATPase, which forms the $\mathrm{H}^{+}$-gradient. Previously, we have shown that the addition of SNAP/+DTT to synaptosomes caused a dissipation of the synaptic vesicle proton gradient that is most likely the result of cytosolic ATP depletion owing to inhibition of mitochondrial respiration by nitric oxide [15]. The maximum of $\mathrm{H}^{+}$-gradient dissipation was observed at the $10^{\text {th }} \mathrm{min}$ that is fully correlated in time with the maximum of $\left[{ }^{3} \mathrm{H}\right] \mathrm{GABA}$ release from cytosol pool. The vesicular proton gradient was restored at the $15^{\text {th }}$ min of incubation with SNAP+DTT and this process coincided with a decrease in the extrasynaptosomal concentration of $\left[{ }^{3} \mathrm{H}\right] \mathrm{GABA}$ (Fig. $1, A$ ) and its re-accumulation inside vesicles (Fig. 3).

Thus, considering the above results, we can conclude that in the nanomolar range of concentrations, nitric oxide in the form of S-nitrosothiols in the presence of SH-reducing compounds may cause $\mathrm{Ca}^{2+}$-independent GABA release from synaptic vesicles into cytosol followed by its release from nerve terminals presumably due to reverse operation of GABA transporters. This process is accompanied by a decrease in the concentration of neurotransmitter within the vesicles and, hence by a decrease in further GABA release by exocytosis. This view on the mechanism of presynaptic action of nitric oxide allows reconciling the contradictory literature data that have shown both stimulating [26] and inhibitory [27] effects of NO on the neurotransmission. A similar opinion about multidirectional action of NO has been previously expressed by other researches $[3,7]$, in particular, Sequeira et al. believe that NO affecting the GABAergic terminals inhibits the exocytotic and stimulates carrier-mediated GABA release [7]. However, unlike Sequeira, we assume that the decrease in neurotransmitter release by exocytosis occur not so much due to the inhibition of the process itself, but rather to the release of partially depleted vesicles.

In summary, it should be noted that it is quite possible that the effect of nitric oxide on GABAergic neurotransmission may be realized by the involvement of other pathways, in particular in case of higher NO concentrations, since a high oxidative potential of nitric oxide provides this molecule with unique properties.

\section{ВПЛИВ ДОНОРА ОКСИДУ АЗОТУ SNАР НА ВИВІЛЬНЕННЯ ГАМК IЗ НЕРВОВИХ ЗАКІНЧЕНЬ МОЗКУ ЩУРIВ}

\section{A. С. Тарасенко}

\author{
Інститут біохімії ім. О. В. Палладіна \\ НАН України, Київ; \\ e-mail: tas@biochem.kiev.ua
}

У роботі ми досліджували вплив наномолярних концентрацій оксиду азоту на вивільнення ГАМК (гама-аміномасляної кислоти) 3 нервових закінчень мозку щурів. Для цього використовували радіоізотопний метод із $\left[{ }^{3} \mathrm{H}\right]$ ГАМК та спектрофлуориметричний метод із застосуванням $\mathrm{Ca}^{2+}$-чутливого зонда Fluo-4 AM. Показано, що в присутності дитіотреїтолу (ДТТ) донор оксиду азоту SNAP у концентрації, що виділяє $\mathrm{NO}$ в наномолярному діапазоні, спричинює $\mathrm{Ca}^{2+}$-незалежне вивільнення $\left[{ }^{3} \mathrm{H}\right]$ ГАМК із нервових закінчень. Застосування 4-амінопіридину (4-АП) та ніпекотинової кислоти (НК) як індукторів вивільнення ГАМК із везикулярного та цитоплазматичного пулів показало, що максимум SNAP/+ДТТ-індукованого вивільнення $\left[{ }^{3} \mathrm{H}\right]$ ГАМК припадає на 10-ту хв інкубації і збігається в часі з майже вдвічі збільшеним

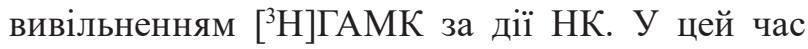
4-АП-індуковане вивільнення [3ㄱ]ГАМК істотно знижувалося. На 15-й хв інкубації синаптосом із SNAP+ДTT спостерігалася протилежна картина: зменшення НК- і збільшення 4-АП-

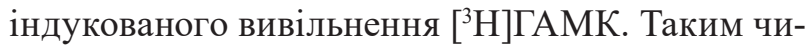
ном, у наномолярному діапазоні концентрацій 
оксид азоту у вигляді $\mathrm{S}$-нітрозотіолів зумовлює $\mathrm{Ca}^{2+}$-незалежне витікання ГАМК із синаптичних везикул у цитозоль із наступним його вивільненням із нервових терміналей. У подальшому відбувається зворотне захоплення нейромедіатора $\mathrm{i}$ його реакумуляція в синаптичних везикулах.

Ключов і слова: оксид азоту, вивільнення ГАМК, везикулярний та цитоплазматичний пул.

\section{ВЛИЯНИЕ ДОНОРА ОКСИДА АЗОТА SNAP НА ВЫСВОБОЖДЕНИЕ ГАМК ИЗ НЕРВНЫХ ОКОНЧАНИЙ МОЗГА КРЫС}

\section{А. С. Тарасенко}

Институт биохимии им. А. В. Палладина НАН Украины, Киев; e-mail: tas@biochem.kiev.ua

В работе мы исследовали влияние наномолярных концентраций оксида азота на высвобождение ГАМК (гамма-аминомасляной кислоты) из нервных окончаний мозга крыс. Для этого использовали радиоизотопный метод с $\left[{ }^{3} \mathrm{H}\right]$ ГАМК и спектрофлуориметрический метод с $\mathrm{Ca}^{2+}$-чувствительным зондом Fluo-4 AM. Показано, что в присутствии дитиотреитола (ДТТ) донор оксида азота SNAP в концентрации, выделяющей NO в наномолярном диапазоне, вызыва-

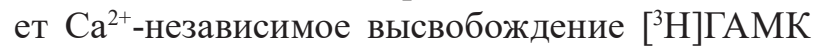
из нервных окончаний. Применение 4-аминопиридина (4-АП) и нипекотиновой кислоты (НК) в качестве индукторов высвобождения ГАМК с везикулярного и цитоплазматического пулов показало, что максимум SNAP+ДTT-

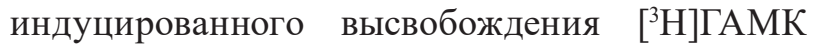
приходится на 10-ю мин инкубации и совпадает по времени с почти вдвое увеличенным высво-

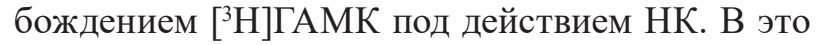
время 4-АП-индуцированное высвобождение

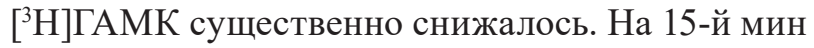
инкубации синаптосом с SNAP+ДТТ наблюдалась противоположная картина: уменьшение НК- и увеличение 4-АП-индуцированного вы-

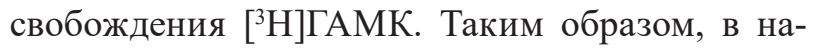
номолярном диапазоне концентраций оксид азота в виде $\mathrm{S}$-нитрозотиолов вызывает $\mathrm{Ca}^{2+}$ независимое вытекание ГАМК из синаптических везикул в цитозоль с последующим его высвобождением из нервных терминалей. В дальнейшем происходит обратный захват нейромедиатора и его реаккумуляция в синаптических везикулах.

К л ю че в ы е с л о в а: оксид азота, высвобождение ГАМК, везикулярный и цитоплазматический пул.

\section{References}

1. Bradley SA, Steinert JR. Nitric Oxide-Mediated Posttranslational Modifications: Impacts at the Synapse. Oxid Med Cell Longev. 2016; 2016: 5681036.

2. Hardingham N, Dachtler J, Fox K. The role of nitric oxide in pre-synaptic plasticity and homeostasis. Front Cell Neurosci. 2013; 7: 190.

3. Pan ZH, Segal MM, Lipton SA. Nitric oxiderelated species inhibit evoked neurotransmission but enhance spontaneous miniature synaptic currents in central neuronal cultures. Proc Natl Acad Sci USA. 1996; 93(26): 15423-15428.

4. Cserép C, Szabadits E, Szőnyi A, Watanabe M, Freund TF, Nyiri G. NMDA receptors in GABAergic synapses during postnatal development. PLoS One. 2012; 7(5): e37753.

5. Wang S, Teschemacher AG, Paton JF, Kasparov S. Mechanism of nitric oxide action on inhibitory GABAergic signaling within the nucleus tractus solitarii. FASEB J. 2006; 20(9): 1537-1539.

6. Ohkuma S, Katsura M, Chen DZ, Narihara H, Kuriyama K. Nitric oxide-evoked $\left[{ }^{3} \mathrm{H}\right]$ gammaaminobutyric acid release is mediated by two distinct release mechanisms. Brain Res $\mathrm{Mol}$ Brain Res. 1996; 36(1): 137-144.

7. Sequeira SM, Duarte CB, Carvalho AP, Carvalho CM. Nitric oxide differentially affects the exocytotic and the carrier-mediated release of $\left[{ }^{3} \mathrm{H}\right]$ gamma-aminobutyric acid in rat hippocampal synaptosomes. Brain Res Mol Brain Res. 1998; 55(2): 337-340.

8. Lipton SA, Choi YB, Pan ZH, Lei SZ, Chen HS, Sucher NJ, Loscalzo J, Singel DJ, Stamler JS. A redox-based mechanism for the neuroprotective and neurodestructive effects of nitric oxide and related nitroso-compounds. Nature. 1993; 364(6438): 626-632.

9. Rudkouskaya A, Sim V, Shah AA, Feustel PJ, Jourd'heuil D, Mongin AA. Long-lasting inhibition of presynaptic metabolism and neurotransmitter release by protein 
S-nitrosylation. Free Radic Biol Med. 2010; 49(5): 757-769.

10. Li DP, Chen SR, Finnegan TF, Pan HL. Signalling pathway of nitric oxide in synaptic GABA release in the rat paraventricular nucleus. $J$ Physiol. 2004; 554(Pt 1): 100-110.

11. Knott AB, Bossy-Wetzel E. Nitric oxide in health and disease of the nervous system. Antioxid Redox Signal. 2009; 11(3): 541-554.

12. Matthews JR, Botting CH, Panico M, Morris HR, Hay RT. Inhibition of NF-kappaB DNA binding by nitric oxide. Nucleic Acids Res. 1996; 24(12): 2236-2242.

13. Cotman CW. Isolation of synaptosomal and synaptic plasma membrane fractions. Methods Enzymol. 1974; 31: 445-452.

14. Larson E, Howlett B, Jagendorf A. Artificial reductant enhancement of the Lowry method for protein determination. Anal Biochem. 1986; 155(2): 243-248.

15. Tarasenko AS. The effect of nitric oxide on synaptic vesicle proton gradient and mitochondrial potential of brain nerve terminals. Ukr Biochem J. 2015; 87(6): 64-75.

16. Hu TM, Chou TC. The kinetics of thiol-mediated decomposition of S-nitrosothiols. AAPS J. 2006; 8(3): E485-E492.

17. Meffert MK, Premack BA, Schulman H. Nitric oxide stimulates $\mathrm{Ca}(2+)$-independent synaptic vesicle release. Neuron. 1994; 12(6): 1235-1244.

18. Kaeser PS, Regehr WG. Molecular mechanisms for synchronous, asynchronous, and spontaneous neurotransmitter release. Annu Rev Physiol. 2014; 76: 333-363.

19. Storchak LG, Pozdnyakova NG, Himmelreich NH. Differential effect of protein kinase inhibitors on calcium-dependent and calciumindependent $\left[{ }^{14} \mathrm{C}\right] \mathrm{GABA}$ release from rat brain synaptosomes. Neuroscience. 1998; 85(3): 989997.

20. Szerb JC. Effect of nipecotic acid, a gammaaminobutyric acid transport inhibitor, on the turnover and release of gamma-aminobutyric acid in rat cortical slices. $J$ Neurochem. 1982; 39(3): 850-858.

21. Lonart G, Johnson KM. Characterization of nitric oxide generator-induced hippocampal [3H] norepinephrine release. II. The role of calcium, reverse norepinephrine transport and cyclic 3',5'-guanosine monophosphate. J Pharmacol Exp Ther. 1995; 275(1): 14-22.

22. Raiteri L, Raiteri M. Multiple functions of neuronal plasma membrane neurotransmitter transporters. Prog Neurobiol. 2015 Nov;134:1-16.

23. Falkenburger BH, Barstow KL, Mintz IM. Dendrodendritic inhibition through reversal of dopamine transport. Science. 2001; 293(5539): 2465-2470.

24. Wu Y, Wang W, Díez-Sampedro A, Richerson GB. Nonvesicular inhibitory neurotransmission via reversal of the GABA transporter GAT-1. Neuron. 2007; 56(5): 851865.

25. Richerson GB, Wu Y. Dynamic equilibrium of neurotransmitter transporters: not just for reuptake anymore. $J$ Neurophysiol. 2003; 90(3): 1363-1374.

26. Merino JJ, Arce C, Naddaf A, BellverLandete V, Oset-Gasque MJ, González MP. The nitric oxide donor SNAP-induced amino acid neurotransmitter release in cortical neurons. Effects of blockers of voltage-dependent sodium and calcium channels. PLoS One. 2014; 9(3): e90703.

27. Nedvetsky PI, Konev SV, Rakovich AA, Petrenko SV, Mongin AA. Effects of nitric oxide donors on $\mathrm{Ca}^{2+}$-dependent $\left[{ }^{14} \mathrm{C}\right] \mathrm{GABA}$ release from brain synaptosomes: the role of SH-groups. Biochemistry (Mosc). 2000; 65(9): 1027-1035.

Received 26.07.2016 